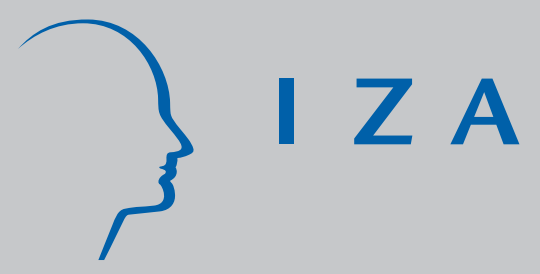

IZA DP No. 2118

Economic Returns to Communist Party Membership: Evidence from Urban Chinese Twins

Hongbin Li

Pak Wai Liu

J unsen Zhang

Ning Ma

May 2006 


\title{
Economic Returns to Communist Party Membership: Evidence from Urban Chinese Twins
}

\author{
Hongbin Li \\ Chinese University of Hong Kong \\ Pak Wai Liu \\ Chinese University of Hong Kong \\ Junsen Zhang \\ Chinese University of Hong Kong \\ and IZA Bonn \\ Ning Ma \\ Johns Hopkins University
}
Discussion Paper No. 2118
May 2006

IZA
P.O. Box 7240
53072 Bonn
Germany

Phone: +49-228-3894-0

Fax: +49-228-3894-180

Email: iza@iza.org

\begin{abstract}
Any opinions expressed here are those of the author(s) and not those of the institute. Research disseminated by IZA may include views on policy, but the institute itself takes no institutional policy positions.

The Institute for the Study of Labor (IZA) in Bonn is a local and virtual international research center and a place of communication between science, politics and business. IZA is an independent nonprofit company supported by Deutsche Post World Net. The center is associated with the University of Bonn and offers a stimulating research environment through its research networks, research support, and visitors and doctoral programs. IZA engages in (i) original and internationally competitive research in all fields of labor economics, (ii) development of policy concepts, and (iii) dissemination of research results and concepts to the interested public.
\end{abstract}

IZA Discussion Papers often represent preliminary work and are circulated to encourage discussion. Citation of such a paper should account for its provisional character. A revised version may be available directly from the author. 


\section{ABSTRACT \\ Economic Returns to Communist Party Membership: Evidence from Urban Chinese Twins*}

This paper estimates the returns to membership of the Chinese Communist Party using unique twins data we collected from China. Our OLS estimate shows that being a Party member increases earnings by $10 \%$, but the within-twin-pair estimate becomes zero. One interpretation of these results is that the OLS Party premium is due to omitted ability and family background. This interpretation would suggest that Party members fare well not because of their special political status per se, but because of the superior ability that made them Party members. The estimates are also consistent with an alternative interpretation that Party membership not only has its own effect but also has an external effect on the sibling.

JEL Classification: J31, O15, P26

Keywords: $\quad$ twins, communist party membership, China

Corresponding author:

Junsen Zhang

Department of Economics

Chinese University of Hong Kong

Shatin, NT

Hong Kong

Email: jszhang@cuhk.edu.hk

\footnotetext{
"We thank Simon Fan, Lok-Sang Ho, Justin Yifu Lin, Jorn-Steffen Pischke (editor), Mark Rosenzweig, Yasuyuki Sawada, Yasuyuki Todo, Xiangdong Wei, two anonymous referees, and seminar and conference participants for very helpful comments and suggestions. We also thank Mark Rosenzweig for his generous help in the survey work. The work described in this paper was substantially supported by a grant from the Research Grants Council of the Hong Kong Special Administative Region (Project no. CUHK4358/01H). The usual disclaimer applies.
} 
There is a growing interest among economists in measuring the value of political status and connections in both developed and developing countries (Roberts, 1990; Fisman, 2001; Agrawal and Knoeber, 2001; Johnson and Mitton, 2003; Bertrand et al., 2004; Khwaja and Mian, 2005; Faccio, 2006). In the context of China, many economists and other social scientists have attempted to measure the returns to being a member of the Chinese Communist Party (Szelenyi, 1987; Nee, 1989, 1991, 1996; Rona-Tas, 1994; Walder, 1996; Morduch and Sicular, 2000; Lam, 2003; Li, et al., 2005, 2006; Liu, 2003). ${ }^{1}$ Many studies have found that Party membership has had positive value for business and personal income during China's economic transition, and that Party members have quickly turned their political advantages into economic benefits by securing high-paying jobs in monopolistic state-owned enterprises and the government.

However, despite the accumulation of large quantities of evidence on the relationship between Party membership and economic benefits, the estimates of the effect of the Party membership are generally subject to bias. An ordinary least squares (OLS) estimation of the effect of Party membership on earnings is very likely to be biased, because Party members may have high earnings due to greater ability or a more advantageous family background. ${ }^{2}$ Thus, Party membership may be correlated with the effects of unobserved ability or family background, ${ }^{3}$ which would create a spurious correlation between membership and earnings. Most studies of the returns to Chinese Communist Party membership, and of the value of political connections in general, give only limited information on individual characteristics, and thus unobserved heterogeneity may confound any causal inference.

In this paper, we attempt to empirically measure the value of Chinese Communist Party membership on an individual's earnings. The main innovation of this paper is to control for the effects of omitted ability and family background by using unique twins data

\footnotetext{
${ }^{1}$ The Communist Party of China (CPC) was founded in 1921. Led by Mao Zedong, it won the Chinese civil war and founded the People's Republic of China in 1949. The CPC is now probably the largest party in the world, with more than 70 million members.

${ }^{2}$ Some studies (e.g., Lam (2003)) use the Heckman model to correct for selection, but it is generally hard to find convincing identifying variables for Party membership.

${ }^{3}$ Many aspects of family background, such as wealth, parental education, family size and structure and family environment, can affect earnings.
} 
that two of the authors collected in urban China. As twins are genetically similar and have the same family background, they should be subject to similar effects of unobserved ability or family background. Looking at the within-twin-pair difference will greatly reduce the effects of unobserved ability and family background that have caused bias in the OLS estimation of the returns to Party membership in previous studies. Intuitively, by contrasting the earnings of twins with and without Party membership, we can be more confident that any correlation observed between Party membership and earnings is not due to a correlation between Party membership and an individual's ability or family background.

The empirical results drawing on twins data are consistent with the hypothesis that the effects of Party membership are due to unobserved ability or family background. Our OLS estimates that control for age, gender, education, and location show that being a Party member increases an individual's earnings by $10 \%$. Interestingly, once we use the within-twin-pair fixed-effects model, the effect of Party membership all but disappears. One interpretation of these results is that the estimated returns to Party membership, as found by the OLS model, is due to the effects of omitted ability or family background. This finding is confirmed by generalized least squares estimations that also include the sum of the two twins' Party membership as a covariate.

The hypothesis that Party members are of higher ability than the average Chinese could be well grounded, given the unique way in which the Party selects its members. ${ }^{4}$ The selection process begins with an adult individual submitting a formal application to a Party branch in their work unit to express their desire to become a member. ${ }^{5}$ The applicant is then monitored for at least three years, during which time they must make a consistent effort to meet all of the Party standards. Each applicant is assigned two Party member liaisons who monitor and assess the applicant's political loyalty, work performance, social activities, and relationships with co-workers, neighbors, and other people on a regular basis. When the Party branch believes that it is time to make a more thorough evaluation, usually about two

\footnotetext{
${ }^{4}$ See Bian et al. (2001) for the detailed selection mechanisms of the Party.

${ }^{5}$ Before applying for Party membership, most people have joined the Communist Youth League of China. However, joining the Youth League is superficial rather than being one of the Party selection criteria, as most young people are members.
} 
years after application, it seeks opinions about the applicant from co-workers who are not Party members and then has a closed-door evaluation meeting that involves all of the Party members in the branch. Any serious doubt on the part of either a non-Party co-worker or a Party member could mean failure, and the applicant will be given time to improve before being considered for another closed-door evaluation. If the potential candidate passes the closed-door evaluation, then they will become a probationary Party member. Probationary Party members are then closely monitored by the Party branch for another year before becoming formal Party members.

This lengthy and extended selection procedure not only ensures the political loyalty of applicants, but also ensures the superior quality of Party members. To become a Party member, an individual needs to show great ability by outperforming co-workers, good interpersonal skills through the maintenance of good relations with co-workers, great persistence by performing well throughout the long selection process, and generally a positive attitude toward communist ideology, society, and work. Work ability, interpersonal skills, persistence, and a positive attitude are important qualities for the success of an individual in both their social life and their career. In fact, some sociologists (Szelenyi, 1987; Lin and Bian, 1991; Walder, 1995) view Party membership as a credential like educational qualifications.

Our further analysis suggests that the size of the earnings premium and the effect of unobserved factors differ across generations. Our OLS estimates with the interaction term of age and Party membership show that only older Party members enjoy an earnings premium. However, the earnings premium for the older generation can be fully explained by unobserved ability. The difference in the effect of unobserved ability across age may be due to the interruption of the education of the older generation during the Cultural Revolution. More importantly, it may also be due to the declining attractiveness of Party membership for the younger generation. Although the Communist Party still rules China, the Communist ideology and role of the Party and the government in the economy have weakened after more than two and a half decades of economic transition.

We also conduct a series of sensitivity tests on the within-twin-pair fixed-effects (FE) 
estimations. In particular, we find that simultaneity, omitted variables and measurement error are not the major reasons that have driven the fixed-effects results. Thus, we are confident that the FE estimates should be less biased than the OLS estimates. We also test whether within-family externality has driven our FE results by using both a modified GLS model and estimations based on the non-twin sibling data we collected. In general, our tests are not powerful enough to dismiss within-family externality. Thus, readers should keep this caveat in mind.

In addition to contributing to the growing body of literature on the value of Party membership in China, our study also contributes to the general literature that measures the value of political connections and political status. The most difficult task in such research is also to solve omitted variable bias. Because of the difficulty in directly measuring the value of political connections, Roberts (1990) and Fisman (2001) have sought to measure it indirectly by making use of special political events to solve the omitted variable bias. By using a sample of twins, we provide a method of directly measuring the value of political status without the complication of omitted variable bias.

Our paper has several limitations. First, we only draw on data from urban China, and the results may not apply to rural China. The proportion of Party members is much larger in urban China than rural China. ${ }^{6}$ Political rents could be larger in rural China, as Party members are more likely to have wage employment and market-oriented, high-value agricultural production (Morduch and Sicular, 2000). Second, like any other studies in the literature of economics, sociology, and political science, we are not able to measure intangible income, such as bribes, perks or side payments. We find that Party members are more likely to hold government positions, which suggests that they may be more likely to have intangible income than non-party members. However, our study still provides important evidence that the literature on the returns to Communist Party membership should be re-evaluated, because it is completely based on the OLS estimates of the Party premium. Finally, although the FE estimates using twins are less biased than the OLS estimates in our contexts, it may

\footnotetext{
${ }^{6}$ For example, Morduch and Sicular (2000) find that $4 \%$ of the rural households have Party members, in contrast to $20 \%$ of the individuals in our urban sample that are Party members.
} 
not remove all bias.

This paper is organized as follows. Section 1 describes the estimation methods that draw on the twins data. Section 2 describes the data and variables. Section 3 empirically measures the returns to Party membership, and Section 4 presents sensitivity tests. Section 5 concludes.

\section{Method}

Our empirical work focuses on the estimation of the log earnings equations that are given as

$$
\begin{aligned}
& y_{1 i}=X_{i} \alpha+\beta_{1} P_{1 i}+Z_{1 i} \beta_{2}+\mu_{i}+\epsilon_{1 i} \\
& y_{2 i}=X_{i} \alpha+\beta_{1} P_{2 i}+Z_{2 i} \beta_{2}+\mu_{i}+\epsilon_{2 i}
\end{aligned}
$$

where $y_{j i}(j=1,2)$ is the logarithm of the earnings of the first and second twin in the pair in family i. $X_{i}$ is the set of observed variables that vary across families but not across twins: that is, the family background variables. $P_{j i}(j=1,2)$ is the Party membership dummy for twin $j$ in family $i$, and $Z_{j i}(j=1,2)$ is a set of observed variables that vary across the twins. $\mu_{i}$ represents a set of unobservables that also affect earnings: that is unobserved ability or the family effect. $\epsilon_{i j}(j=1,2)$ is the disturbance term. The ordinary least squares (OLS) estimate of the Party membership effect in equation (1), $\beta_{1}$, is generally biased. The bias arises because normally we do not have a perfect measure of $\mu_{i}$, which is very likely to be correlated with $P_{i}$.

A within-twin-pair fixed-effects estimator for twins is based on the first difference between Equations (1) and (2):

$$
y_{1 i}-y_{2 i}=\beta_{1}\left(P_{1 i}-P_{2 i}\right)+\left(Z_{1 i}-Z_{2 i}\right) \beta_{2}+\epsilon_{1 i}-\epsilon_{2 i} .
$$

The first difference removes both observable and unobservable family effects, or $X_{i}$ and $\mu_{i}$. As $\mu_{i}$ has been removed, we can apply the OLS method to Equation (3) without worrying about bias being caused by the omitted ability and family background variables.

Alternatively, we can directly estimate both the bias and the Party effect using the approach that was developed by Ashenfelter and Krueger (1994). This approach also draws 
on data from twins. In this approach, the correlation between the unobserved family effect and the observables is given as

$$
\mu_{i}=\gamma P_{1 i}+\gamma P_{2 i}+Z_{1 i} \theta+Z_{2 i} \theta+X_{i} \delta+\omega_{i}
$$

where we assume that the correlations between the family effect $\mu_{i}$ and the Party status of each twin $P_{j i}(j=1,2)$ and the characteristics of each twin $Z_{j i}(j=1,2)$ are the same. We further assume that $\omega_{i}$ is uncorrelated with $P_{j i}(j=1,2), Z_{j i}(j=1,2)$ and $X_{i}$. The coefficient $\gamma$ measures the selection effect that relates family effect to Party status, and the vector of coefficients $\theta$ measures the selection effect that relates family effect to other individual characteristics.

The reduced form for equations (1), (2), and (4) is obtained by substituting (4) into (1) and (2) and collecting the terms as follows.

$$
\begin{aligned}
& y_{1 i}=X_{i}(\alpha+\delta)+\left(\beta_{1}+\gamma\right) P_{1 i}+\gamma P_{2 i}+Z_{1 i}\left(\beta_{2}+\theta\right)+Z_{2 i} \theta+\epsilon_{1 i}^{\prime} \\
& y_{2 i}=X_{i}(\alpha+\delta)+\left(\beta_{1}+\gamma\right) P_{2 i}+\gamma P_{1 i}+Z_{2 i}\left(\beta_{2}+\theta\right)+Z_{1 i} \theta+\epsilon_{2 i}^{\prime},
\end{aligned}
$$

where $\epsilon_{j i}^{\prime}=\omega_{i}+\epsilon_{j i},(j=1,2)$. Equations (5) and (6) are estimated using the generalized least squares (GLS) method, which is the best estimator that allows cross-equation restrictions on the coefficients. Although both the fixed-effects and the GLS models control for ability and can produce unbiased estimates of the Party effect $\beta_{1}$, GLS also allows the estimation of the selection effect $\gamma$.

\section{Data}

The data that we use are derived from the Chinese Twins Survey, which was carried out by the Urban Survey Unit of the National Bureau of Statistics in June and July 2002 in five cities in China. The survey was funded by the Research Grants Council of Hong Kong. Based on twins questionnaires from the United States and elsewhere, the survey covered a wide range of socioeconomic information. The questionnaire was designed by two authors of this paper in close consultation with Mark Rosenzweig and Chinese experts at the National Bureau of Statistics. Adult twins who were aged between 18 and 65 years (the 1942-1986 
birth cohort) were identified by the local Bureau of Statistics through various channels, including colleagues, friends, relatives, newspaper advertisements, neighborhood notices, neighborhood management committees, and household records in the public security bureau. The questionnaires were completed through household face to face personal interviews. The survey was conducted with considerable care, and several site checks were made by Junsen Zhang and experts from the National Bureau of Statistics. After appropriate discussion with Mark Rosenzweig and other experts, the data input was closely supervised and monitored by Junsen Zhang himself in July and August 2002.

This is the first socioeconomic dataset on twins in China and perhaps the first in Asia. The dataset includes detailed socioeconomic information on respondents from households in five cities: Chengdu, Chongqing, Harbin, Hefei, and Wuhan. Altogether, there are 4,683 observations, of which 3,012 are from households with twins. We have completed questionnaires from 3,002 individuals, of which 2,996 are twin individuals and 6 are triplet individuals. Of these 3,002 individuals, we have complete information on 1,873 individuals, and complete information for both twins in the pair is available for 725 twin pairs (1450 individuals).

For comparison, non-twin households in the five cities were taken from regular households with whom the Urban Survey Unit conducts regular monthly surveys. The Urban Survey Unit started regular monthly surveys in the 1980s. Their initial samples were random and representative, and although they have made every effort to maintain these good sampling characteristics, their samples have become less representative over time. In particular, given the increasingly high refusal rate of young people, the samples have gradually become biased toward the over sampling of old people. The survey of non-twin households was conducted at the same time as the twin survey using a similar questionnaire.

The descriptive statistics are reported in Table 1. Although our within-twin-pair estimations control for possible sample selection, ${ }^{7}$ it is interesting to compare the twins sample to the other samples that we have. To aid such a comparison, we also provide the basic statistics for a large-scale survey that was conducted by the National Bureau of Statistics as a

\footnotetext{
${ }^{7}$ The within-twins estimation that is used for this study controls for the first-order effects of any unobserved characteristics that might have led to the selection of pairs of twins for the sample.
} 
benchmark. $^{8}$ In column 1 , we report the mean of all of the variables for twins. Sixty percent of these twins were male who, on average, were 34 years old and had 12 years of schooling. Twenty percent of them were Party members who, ${ }^{9}$ on average, had monthly earnings of 875 yuan, where earnings included wages, bonuses, and subsidies. ${ }^{10}$ The individuals in the twins sample were younger and earned less than those in the National Bureau of Statistics sample. ${ }^{11}$ Finally, the individuals in the non-twins sample (column 3) were older than those in the National Bureau of Statistics sample and in the twins samples.

To obtain a well performing within-twin-pair estimation of the returns to Party membership, the within-twin-pair variation of Party membership must be sufficiently large. Generally speaking, the within-twin-pair variation is reasonably large. In $68 \%$ of the sets of twins neither twin was a Party member, in $22 \%$ one of the twins was a Party member, and in $10 \%$ both twins were Party members.

\section{Results}

In this section, we report the estimated returns to Party membership using different samples and methods. We start with OLS regressions using the whole sample, which includes twins and non-twins, and then conduct the same OLS estimations using the twins sample to compare the estimated coefficients to those that are estimated using the whole sample. This comparison serves as a way to check the representativeness of the twins sample. We then conduct the within-twin-pair fixed-effects and GLS estimations using the twins sample. ${ }^{12}$

\footnotetext{
${ }^{8}$ The National Bureau of Statistics has been conducting an annual survey of urban households from 226 cities (counties) in China since 1986. It is the best large-scale survey of this kind. However, the NBS only allows us to use its data from six provinces, including Beijing, Liaoning, Sichuan, Shaanxi, Zhejiang and Guangdong.

${ }^{9}$ The NBS data do not contain information on the Party membership. We check it with other samples, and find the proportion of Party members in our sample is in line with other samples. For example, it is $18.4 \%$ in the sample of Lam (2003) collected from Shanghai and $23 \%$ in the CASS sample collected from 11 provinces by Li Shi and his colleagues.

${ }^{10} \mathrm{As}$ our focus is on wage earnings, we drop observations with zero wage earnings for either twin in a pair for the twins sample, and drop all individuals with zero earnings for the non-twins sample. The employment rates for the twins and non-twins samples are 0.939 and 0.947 , and thus selection is not a major issue.

${ }^{11}$ Only one of our cities is in the NBS sample. The six provinces in the NBS sample include the three richest provinces in China: Beijing, Zhejiang and Guangdong, and thus have larger average earnings than our sample.

${ }^{12}$ In the twins sample, we can distinguish whether they are identical or non-identical twins. We consider a pair of twins to be identical if both twins responded that they have identical hair color, look and gender. As the results using identical twins are very similar to those using all twins, we only report those using all
} 
Finally, we examine whether the Party effect varies with age, leaving the sensitivity analyses to the next section.

\subsection{OLS Regressions}

In the first column of Table 2, we report the results of the OLS regression using the whole sample that includes both twins and non-twins. The dependent variable is the logarithm of monthly earnings. Independent variables include the Party membership dummy, age, age squared, gender, years of education, and city dummies. We calculate the standard errors allowing heteroscadesticity and clustering at the family level.

The regression shows that the returns to Party membership are quite large: being a Party member increases earnings by $12.4 \%$, which is precisely estimated with a standard error of 0.023 . Other variables in column 1 also have the expected signs. Men have $18.9 \%$ higher earnings than women, and there is a concave relationship between earnings and age. The positive coefficient of age and the negative coefficient of age squared are both significant at the $5 \%$ level. Wage increases with age before the age of 52 and starts to drop thereafter. As expected, education itself has a positive effect on earnings. An additional year of education increases earnings by $6.3 \%$, which is comparable to the estimated returns to education in previous studies that draw on Chinese data (Zhang et al., 2005).

In column 2, we repeat the same OLS regressions using the twins sample. Comparing the OLS results of the whole sample with those of the twins sample is a way of checking the representativeness of our twins sample. As we only use twin pairs with complete information for both twins, the sample size is reduced to 1450 (or 725 pairs of twins). Generally, our twins sample is fairly representative. The estimated coefficients for most of the variables are similar to those that are reported in column 1.

To summarize, the OLS estimates of the Party membership effect are rather large even when we control for many of the covariates. The remaining effect of Party membership is 0.100 in column 2. However, we still do not know how much of this effect is the real Party membership effect, such as political connections or the job privileges that are associated with twins, as suggested by the editor. 
Party membership, and how much is due to unobserved ability or family background. We will tackle this issue by the fixed-effects and GLS estimations next.

\subsection{Fixed-Effects and GLS Estimations}

In column 3 of Table 2, we report the results of the within-twin-pair fixed-effects (FE) estimation, or the estimation of Equation (3). As twins have the same age and gender, these two variables are dropped when assessing the first difference.

The fixed-effects estimation shows that much of the Party membership effect that is found in the OLS estimations is gone. The fixed-effects estimate of the Party membership effect is 0.011 , which is only $11 \%$ of the OLS estimate using the same twins sample. If the fixed-effects estimate is unbiased, then this result suggests that $89 \%$ of the OLS estimate of the Party effect could be due to the effects of ability or family background. Moreover, the estimated coefficient on the Party dummy in the fixed-effects estimation is not significantly different from zero, which suggests that after removing the effects of ability and family background, the pure Party membership effect is zero.

We next turn to the GLS estimator for Equations (5) and (6), which can directly estimate both the Party membership effect and the ability or family effect. In column 4 of Table 2, we report the GLS estimate that includes all of the covariates that are used in the OLS estimates. In addition to the Party membership dummy, we also include the sum of the Party membership dummies of both twins in a pair $\left(P_{1 i}+P_{2 i}\right)$ as an independent variable. The coefficient of this new variable will be the estimated effect of ability or family background, that is, $\gamma$ in Equations (5) and (6). Similarly, we also include the sums of education as a covariate to estimate the family effect of education. The GLS model is estimated by stacking Equations (5) and (6) and fitting them using the SURE model.

The GLS estimation again shows that the pure Party effect is small and not significantly different from zero, whereas the effects of omitted ability and family background could be large. The coefficient of an individual's Party membership is only 0.013 , which is very close to the FE estimate. In contrast, the estimated family effect, that is, the coefficient of the 
sum of the Party membership dummy of both twins in a pair, is much larger than the pure Party effect and is significantly different from zero.

\subsection{Old versus Young Workers}

Although the Communist Party still rules China, the Communist ideology and the role of the Party and government in the economy have weakened after more than two and half decades of economic transition from a centrally planned to a market economy. The most important change in this period has been the entrance of non-state firms, including private, collective, and foreign firms, into the economy. In 2002, the non-state sector employed $70 \%$ of workers in China, and produced two thirds of the GDP. Because of the development of the non-state sector (which values Party membership less than the state sector) and the weakening of the Communist ideology, the return to the Party membership may decline over time and joining the Party may become less attractive for the younger generation. The unobserved ability or selection effect may also be more important for the older generation because the Cultural Revolution during 1966-1976 interrupted the education and career of many Chinese who were born between 1950 and 1968. As a result, education and job experience may not fully pick up the ability of these people, and furthermore the political fever in this period understandably made joining the Party very rewarding for individuals with great ability.

We next test whether the returns to Party membership and the selection effect (the effect of observed and unobserved ability) differ for the older and younger generations. In the last two columns of Table 2, we report the OLS and FE estimations of the returns to Party membership including the interaction of the Party membership and age as an additional covariate. Note that the Party membership dummy is negative and significant at the $10 \%$ level and the interaction term is positive and significant at the $1 \%$ level for the OLS specification (column 5). The OLS regression suggests that the Party effect is increasing with age, and the magnitude of the coefficients suggest that the Party membership has a positive effect only after age 29. Interestingly, once we take the within-twin-pair difference, both the Party effect and the interaction effect are gone (column 6). These results are consistent with 
the hypothesis that Party members in the older generation have a higher unobserved ability than non-party members, and there are no returns to Party membership per se.

\section{Robustness of Findings}

In this section, we conduct a series of sensitivity tests on the fixed-effects estimations. In particular, we will examine to what extent omitted variables, measurement error and simultaneity have biased the fixed-effects estimations. We will also examine whether there is within-family externality with the Party membership.

\subsection{Omitted Variable Biases}

One major concern of the within-twin-pair estimate is whether it is less biased than the OLS estimate, and therefore a better estimate. Bound and Solon (1999) and Neumark (1999) argue that although taking a within-twin-pair difference removes genetic variation, or $\mu_{i}$, from Equation (3), this difference may still reflect the ability bias to the extent that ability consists of more than just genes. In other words, a within-twin-pair estimation may not completely eliminate the bias of the conventional cross-sectional estimation, because the within-twin-pair difference in ability may remain in $\epsilon_{1 i}-\epsilon_{2 i}$ in Equation (3), which may correlate with $P_{1 i}-P_{2 i}$.

Although within-twin-pair estimation cannot completely eliminate the bias of the OLS estimator, it can tighten the upper bound of the return to Party membership. Ashenfelter and Rouse (1998), Bound and Solon (1999) and Neumark (1999) have all debated the bias in the OLS and within-twin-pair estimations at length. If the Party membership and the earnings error term are positively correlated both in the cross-sectional and within-twin-pair regressions, and if the endogenous variation within a family is smaller than the endogenous variation between families, then we can assume that the fixed-effects estimator is less biased than the OLS estimator. ${ }^{13}$ Thus, the fixed-effects estimator can be regarded as an upper

\footnotetext{
${ }^{13}$ The Party membership may also be negatively correlated with the error term. For example, if non-party members invest more into business skills, then the Party membership is negatively correlated with the error term (business skills). In this example, there is a downward bias of the estimated Party effect. As this kind of bias is individual-specific, the within-twin-pair estimation cannot remove it. However, this kind of bias should exist for both OLS and FE models, and thus the FE model can still improve our estimations by
} 
bound of the return to Party membership.

To examine whether the within-twin-pair estimate is less biased than the OLS estimate, we follow Ashenfelter and Rouse (1998) and conduct a correlation analysis. We use the correlations of average family Party membership over each pair of twins with the average family characteristics that may be correlated with ability (for example, education, tenure, marital status and spouse education) to indicate the expected ability bias in a cross-sectional OLS regression. We then use the correlations of the within-twin-pair difference in Party membership and the within-twin-pair differences in these characteristics to indicate the expected ability bias in a within-twin-pair regression. If the correlations in the cross-sectional case are larger than those in the within-twin-pair case, then the ability bias in the cross-sectional OLS regressions is likely to be larger than that in the within-twin-pair regressions.

The correlation tests that are reported in Table 3 suggest that the within-twin-pair estimations of the returns to Party membership may indeed be less affected by omitted variables than the OLS estimations. Note that the between-family correlations are all larger in magnitude than the within-twin-pair correlations. For example, the correlation between average family Party membership and average family education is 0.23 (column 2) and significantly different from zero, which suggests that families with a lower average level of education have fewer Party members. This is consistent with the assumption that ability and family background positively affect Party membership status. The correlation of withintwin-pair difference in Party membership and the within-twin-pair difference in education is much smaller than that of the between-family correlation. This suggests that, to the extent that education measures ability, within-twin-pair differences in Party membership are less affected by the ability bias than the family-average of Party membership variable. However, this within-twin-pair correlation is still statistically significant and large in magnitude, which implies that the within-twin-pair difference cannot completely eliminate the ability bias that is embodied in education. Thus, it is necessary to control for the within-twin-pair difference in education in the within-twin-pair estimations of the returns to Party membership.

removing ability at the family level. 
The correlations of Party membership with other variables provide even stronger evidence that the within-twin-pair estimations are subject to a smaller omitted ability bias. The between-family correlations are significant in all but one of these pairs, but none of the within-twin-pair correlations is significant. Of course, these characteristics are only an incomplete set of ability measures, but the evidence is suggestive.

\subsection{Measurement Error}

Another concern is the measurement error problem. As is well known, classical errors in the measurement of the Party membership lead to a downward bias in the OLS estimate of the effect of the Party membership on earnings, and the fixed effects estimator magnifies such measurement error bias. Although we do not have a good instrumental variable to directly deal with the potential measurement error, we could examine how serious the measurement error is. More specifically, we use the formula derived by Freeman (1984) to calculate the relative bias of the FE estimate versus the OLS estimate. Define $\beta_{F E}$ as the fixed-effect estimate of the return to Party membership and $\beta_{O L S}$ as the OLS estimate, and assume that the measurement errors of the two twins are independent. According to Freeman (1984, Equations (9) and (16)), the ratio $\beta_{F E} / \beta_{O L S}=\sigma_{\Delta P}^{2} / \sigma_{\Delta M}^{2}$, where $\sigma_{\Delta P}^{2}$ is the true variance of the within-twin difference in the Party membership and $\sigma_{\Delta M}^{2}$ is the measured variance.

We can calculate this ratio for different values of the misreporting percentages, given the observed proportion of the Party members and the within-twin difference in the Party membership. If the percentage of individuals in the sample who misreport is $5 \%$, then this ratio is 0.825 . This means that the FE estimate is $82.5 \%$ of the OLS estimate, and it is much larger than the $11 \%$ found in Table 2. Even if $10 \%$ of the sample misreports their Party memberships, the ratio is still $71.4 \% .{ }^{14}$ Therefore, these findings suggest that measurement error is not a major force that has driven the difference between our OLS and FE estimates.

\footnotetext{
${ }^{14}$ Although measurement error is a potential problem, it may not be very serious for the following reasons. First, because being a Communist Party member is a very serious thing, it is impossible for one to forget whether one is a member. It is also unlikely for one to intentionally misreport. Second, it is a dummy variable, and the chance of miss-coding is quite small, especially when we took great effort in monitoring the survey and data entry. Thus, it is highly unlikely that more than $10 \%$ of the sample misreport their Party membership.
} 


\subsection{Simultaneity}

One concern is simultaneity, that is, that those with higher earnings are more likely to join (or to be selected by) the Party. In terms of the within-twin-pair estimations, simultaneity means that in a given pair of twins the twin with higher earnings is more likely to join the Party. If simultaneity is important in our twins sample, then this reverse causality will lead to a positive correlation between the within-twin-pair difference in the Party membership and the within-twin-pair difference in earnings, and would cause the estimated effect of the Party membership on earnings to become biased upward. However, we find the FE estimate of the Party effect to be zero, which suggests that any upward bias that is caused by simultaneity, even if it does exist, is not very important.

\subsection{Within-Family Externality}

Although the FE estimation helps to reduce the bias caused by omitted family background, it may also have eliminated the true return to the Party membership. Suppose that Party membership has an external effect within a family: that is, someone who is not a Party member can nevertheless benefit from having a sibling being a Party member. Under such circumstances, the FE estimation will tend to underestimate the true return to the Party membership. For example, if the own effect of the Party membership equals the external effect, then the two effects will cancel out when we take the within-twin difference and thus the FE estimate will be zero.

We use two methods to address this concern. In the first method, we control for the external effect by directly modeling it. Assume that the external effect happens to twin i only when twin i is not a Party member while his/her co-twin is a Party member. The earnings equation should then be modified as follows,

$$
\begin{aligned}
& y_{1 i}=X_{1 i} \alpha+\beta_{1} P_{1 i}+\lambda\left(1-P_{1 i}\right) P_{2 i}+Z_{1 i} \beta_{2}+\mu_{i}+\epsilon_{1 i} \\
& y_{2 i}=X_{2 i} \alpha+\beta_{1} P_{2 i}+\lambda\left(1-P_{2 i}\right) P_{2 i}+Z_{2 i} \beta_{2}+\mu_{i}+\epsilon_{2 i}
\end{aligned}
$$

where $\lambda$ measures the external effect: that is, the effect of co-twin's Party membership when 
one is not a Party member. Substituting Equation (4) into Equations (7) and (8) yields

$$
\begin{aligned}
& y_{1 i}=X_{i}(\alpha+\delta)+\beta_{1} P_{1 i}+\lambda\left(1-P_{1 i}\right) P_{2 i}+\gamma\left(P_{1 i}+P_{2 i}\right)+Z_{1 i}\left(\beta_{2}+\theta\right)+Z_{2 i} \theta+\epsilon_{1 i}^{\prime} \\
& y_{2 i}=X_{i}(\alpha+\delta)+\beta_{1} P_{2 i}+\lambda\left(1-P_{2 i}\right) P_{1 i}+\gamma\left(P_{1 i}+P_{2 i}\right)+Z_{2 i}\left(\beta_{2}+\theta\right)+Z_{1 i} \theta+\epsilon_{2 i}^{\prime} \cdot(10)
\end{aligned}
$$

We estimate Equations (9) and (10) by the GLS model.

The regression results in column 1 of Table 4 are not strong enough to either accept or dismiss the existence of the external effect. The coefficients for both the own Party membership dummy $\left(\beta_{1}\right)$ and the dummy for only the sibling being a Party member $(\lambda)$ are not statistically significant. However, the coefficients on both variables are large and of similar magnitude to the OLS estimates of the own Party membership effect in Table 2, and the coefficient on the sum of the Party membership $(\gamma)$ is very small. These estimates are consistent with the hypothesis that the Party membership has causal effects on both own and sibling earnings, though these effects are not precisely estimated. The bottom line is that the statistical power of the test may not be great enough to dismiss the existence of the external effect.

In our second method, we use a more general form to estimate the external effect of the Party membership within families using both the twin and non-twin sibling samples. Specifically, we estimate the following equation,

$$
y_{i}=X_{i} a+b_{1} P_{-i}+Z_{i} b_{2}+\epsilon_{i}
$$

where $P_{-i}$ is the Party membership of the sibling. Thus, $b_{1}$ should measure the external effect as well as the uncontrolled ability or family effect.

We first present results using the twins sample. In the second column of Table 4, we report a regression with an individual's own Party membership (same as column 2 of Table 2 ), which has a significant coefficient of 0.100 . In column 3, we report the OLS estimate of Equation (11). Note that the coefficient on the (co-twin) sibling's Party membership has very similar effect on earnings to that of his or her own Party membership as in column 2. These results suggest that for the twins sample, the Party membership of the sibling is 
as important as own Party membership for earnings. Yet, is this externality or unobserved ability?

To answer this question, we perform the same regressions using a sample of nontwin siblings. For our non-twins sample, we also collected information on siblings of the interviewees, though we only know the Party membership of the interviewees. If externality is the major reason and if the externality between twins and non-twin siblings is of a similar magnitude, then using the sample of non-twin siblings should yield similar results as twins: that is, the own effect is about the same as the external effect. However, if omitted ability is the underlying reason, then the sibling's Party membership should be less important in explaining earnings for the non-twin sample.

The regression results that are reported in columns 4-5 seem to suggest that externality may not be the major reason. Although own Party membership is very important for earnings (column 4), the sibling's Party membership is not important for the non-twin sample. The coefficient on the sibling's Party membership in column 4 is only about $20 \%$ of that on the own Party membership, and it is not significantly different from zero. The results for twins and non-twins samples together suggest that co-twin sibling's Party membership has mainly picked up unobserved ability rather than externality.

As a caveat, we should note that one key assumption for the second test to work is that the external effect is of a similar magnitude for twins and non-twin siblings in our sample. However, there might be reasons to believe that the external effect is larger between twins than between non-twin siblings. For example, our sampling scheme may have made it more likely to select twins who live close to each other and thus they may have a larger within-family spillover effect than non-twin siblings in the sample.

\subsection{Other Benefits of Party Members}

Throughout this paper, we have focused on how the Party membership affects tangible labour earnings, the part of earnings that are observable to researchers. We have to admit that, like any other studies in the literature of economics, sociology, and political science, we are 
not able to measure intangible income, such as bribes, perks, and other side payments. ${ }^{15}$

Although we are not able to directly measure bribes and side payments, we could indirectly test how they may be correlated with the Party membership. In China, bribes and side payments are more likely to be paid to those Party members who are government officials. Thus, if Party members are more likely to be government officials, then they probably are more likely to take bribes or side payments. Our regression indeed shows that Party members are more likely to hold government positions. In the last column of Table 4, we report a FE regression with the government official dummy as the dependent variable. ${ }^{16}$ As shown, the Party membership has a positive and significant coefficient even after we control for unobserved ability and family effect. Being a Party member increases the probability of entering the government by $12.3 \%$.

\section{Conclusion}

This paper empirically measures the returns to membership of the Chinese Communist Party by using twins data to control for the effects of omitted ability and family background. Our OLS estimate shows that being a Party member increases earnings by $10 \%$, but the withintwin-pair estimate becomes zero. Our sensitivity analyses suggest that in the absence of within-family externality, the within-twin-pair estimates can at least serve as the upper bound of the true returns to Party membership, and in our case this upper bound is almost zero. We also find that the positive selection effect of Party membership only exists for the older generation, which could be due to its interrupted education or the declining attractiveness of Party membership over time. Our study provides important evidence that the literature on the returns to Communist Party membership should be re-evaluated, because it is completely based on the OLS estimates of the Party premium.

There can be two possible interpretations of our main findings. The first and standard

\footnotetext{
${ }^{15}$ The benefits could also be intergenerational. For example, the children of Party members may receive better education.

${ }^{16}$ We also estimated an earnings equation with the Party membership dummy, the government official dummy and their interaction term as independent variables. We find that the interaction term is not significant, which suggests that Party members working in the government do not have an advantage in terms of tangible incomes compared to those working in the private sector.
} 
interpretation is that the large OLS estimate is due to omitted ability or family background. According to this interpretation, Party members fare well not because of their special political status per se, but because of their higher ability or more advantageous family background. This could occur because the Party has a unique way of selecting its members to ensure their superior quality. The second interpretation is that the within-family external effect of Party membership is of a similar magnitude to the own effect, and thus the two cancel out in the within-twin-pair estimations. Our statistical tests can neither accept nor dismiss the second interpretation.

An interesting question is whether Party members have used their unique political status to exploit non-Party members and become rich during China's economic transition. This may indeed have occurred. If the within-family externality interpretation is true, then Party membership will be important in terms of earnings for both Party members themselves and their family members. Moreover, there is much anecdotal evidence to suggest that some Party members are corrupt. As with any other studies in the literature of economics, sociology, or political science, we are not able to measure intangible income, such as bribes. However, we do show that Party members are more likely to be government officials, who are the potential recipients of bribes.

The survival of Communism in China depends on the Party, and the survival of the Party depends on the quality of its members. If the first interpretation is true, then it means that Party members generally have a higher ability (or better family background) than non-Party members. The high quality of Party members could explain why they have been able to quickly come up with and effectively implement market-based reforms, and why they are able to constantly adapt to the new environment but keep the Communist ideology alive (although it may have weakened in the younger generation). In this sense, its members being China's elite may be an important reason for the success of the Party and of China's reforms. 


\section{References}

Agrawal, A. and Knoeber, C. K. (2001). 'Do some outside directors play a political role?' Journal of Law and Economics, vol. 44, pp. 179-98.

Ashenfelter, O. and Krueger, A. (1994). 'Estimating the returns to schooling using a new sample of twins', American Economic Review, vol. 84(5), pp. 1157-73.

Ashenfelter, O. and Rouse, C. (1998). 'Income, schooling and ability: evidence from a new sample of identical twins’, Quarterly Journal of Economics, vol. 113(1), pp. 253-84.

Bertrand, M., Kramarz, F., Schoar, A. and Thesmar, D. (2004). 'Politically connected CEOs and corporate outcomes: evidence from France’, Unpublished Working Paper.

Bian, Y., Shu, X. and Logan, J. (2001). 'Communist Party membership and regime dynamics in China’, Social Forces, vol. 79(3), pp. 805-41.

Bound, J. and Solon, G. (1999). 'Double trouble: on the value of twins-based estimation of the return to schooling', Economics of Education Review, vol. 18(2), pp. 169-82.

Faccio, M. (2006). Politically-connected firms: Can They Squeeze the State?’ American Economic Review, vol. 96(1), pp. 369-386.

Fisman, R. (2001). 'Estimating the value of political connections', American Economic Review, vol. 91, pp. 1095-102.

Freeman, R. (1984). 'Longitudinal analyses of the effects of trade unions', Journal of Labor Economics, vol. 2(1), pp. 1-26.

Johnson, S. and Mitten, T. (2003). 'Cronyism and capital controls: evidence from Malaysia', Journal of Financial Economics, vol. 67, pp. 351-382.

Khwaja, A. and Mian, A. (2005). Do lenders favor politically connected firms? Rent provision in an emerging financial market', Quarterly Journal of Economics, vol. 120(4), pp. 1371-411.

Lam, K.C. (2003). 'Earnings advantage of Party members in Urban China', Unpublished Working Paper, Hong Kong Baptist University.

Li, H., Meng, L. and Zhang, J. (2006). 'Why do entrepreneurs enter politics? Evidence from China', Economic Inquiry, in print.

Li, H., Meng, L., Wang, Q. and Zhou, L. (2006). 'Political connections and firm performance: evidence from Chinese private firms', Unpublished Working Paper, Chinese University of Hong Kong. 
Lin, N. and Bian, Y. (1991). 'Getting ahead in Urban China', American Journal of Sociology, vol. 97, pp. 657-88.

Liu, Z. (2003), 'The economic impact and determinants of investment in human and political capital in China', Economic Development and Cultural Change, vol. 51(4), pp. 823-50.

Morduch, J. and Sicular, T. (2000). 'Politics, growth, and inequality in Rural China: Does it pay to join the Party? Journal of Public Economics, vol. 77(3), pp. 331-56.

Nee, V. (1989). A theory of market transition-from redistribution to markets in state socialism', American Sociological Review, vol. 54(5), pp. 663-81.

Nee, V. (1991). 'Social inequalities in reforming state socialism - between redistribution and markets in China’, American Sociological Review, vol. 56 (3), pp. 267-82.

Nee, V. (1996). 'The emergence of a market society: changing mechanisms of stratification in China’, American Journal of Sociology, vol. 101 (4), pp. 908-49.

Neumark, D. (1999). 'Biases in twin estimates of the return to schooling', Economics of Education Review, vol. 18(2), pp. 143-48.

Roberts, B. E. (1990). 'A dead senator tells no lies: seniority and the distribution of federal benefits', American Journal of Political Science, vol. 34, pp. 31-58.

Rona-Tas, A. (1994). 'The first shall be last? Entrepreneurship and communist cadre in the transition from socialism', American Journal of Sociology, vol. 100, pp. 40-69.

Szelenyi, S. (1987). 'Social inequality and Party membership: patterns of recruitment into the Hungarian Socialist Workers’ Party’, American Sociological Review, vol. 52, pp. 559-73.

Tunali, I. (1986). 'A general structure for models of double-selection and an application to a joint migration/earnings process with remigration', in (R. Ehrenburg ed.): Research in Labor Economics, 235-83., JAI Press, Greenwich, CT.

Walder, A. (1995). 'Career mobility and the communist political order', American Sociological Review, vol. 60(3), pp. 309-28.

Walder, A. (1996). 'Markets and inequality in transitional economics: toward testable theories', American Journal of Sociology, vol. 101, pp. 1060-73.

Zhang, J., Zhao, Y., Park, A. and Song, X. (2005). 'Economic returns to schooling in Urban China, 1988 to 2001', Journal of Comparative Economics, vol. 33(4), pp.730-52. 
Table 1: Descriptive Statistics of the Twins and Non-Twins Samples

\begin{tabular}{|c|c|c|c|c|}
\hline Variable & $\begin{array}{l}\text { Twins } \\
\text { (all) }\end{array}$ & $\begin{array}{c}\text { Twins } \\
\text { (both twins } \\
\text { have complete } \\
\text { information) }\end{array}$ & Non-twins & NBS sample \\
\hline & (1) & (2) & (3) & (4) \\
\hline Party membership & $\begin{array}{c}0.202 \\
(0.402)\end{array}$ & $\begin{array}{c}0.203 \\
(0.403)\end{array}$ & $\begin{array}{c}0.288 \\
(0.453)\end{array}$ & - \\
\hline Age & $\begin{array}{l}34.050 \\
(9.357)\end{array}$ & $\begin{array}{l}33.044 \\
(8.871)\end{array}$ & $\begin{array}{l}42.204 \\
(8.410)\end{array}$ & $\begin{array}{c}40.800 \\
(11.981)\end{array}$ \\
\hline Male & $\begin{array}{c}0.596 \\
(0.491)\end{array}$ & $\begin{array}{c}0.603 \\
(0.489)\end{array}$ & $\begin{array}{c}0.471 \\
(0.499)\end{array}$ & $\begin{array}{c}0.553 \\
(0.502)\end{array}$ \\
\hline $\begin{array}{c}\text { Earnings (monthly wage, bonus and subsidies } \\
\text { in RMB) }\end{array}$ & $\begin{array}{c}875.394 \\
(571.900)\end{array}$ & $\begin{array}{c}894.292 \\
(538.269)\end{array}$ & $\begin{array}{c}847.517 \\
(551.189)\end{array}$ & $\begin{array}{l}1062.921 \\
(840.092)\end{array}$ \\
\hline Years of education & $\begin{array}{l}12.054 \\
(2.923)\end{array}$ & $\begin{array}{l}12.299 \\
(2.915)\end{array}$ & $\begin{array}{l}11.761 \\
(3.053)\end{array}$ & $\begin{array}{l}11.616 \\
(2.834)\end{array}$ \\
\hline Government official & $\begin{array}{c}0.065 \\
(0.246)\end{array}$ & $\begin{array}{c}0.073 \\
(0.260)\end{array}$ & $\begin{array}{c}0.101 \\
(0.301)\end{array}$ & $\begin{array}{c}0.089 \\
(0.182)\end{array}$ \\
\hline Sample size & 1873 & 1450 & 1262 & 23288 \\
\hline
\end{tabular}

Note: Mean and standard deviation (in parentheses) are reported in the table. The first column includes all individuals from the twins sample for which we have complete information of the above variables. The second column includes only those twin pairs for which we have complete information for both twins in a pair. The NBS sample is based on six provinces. 
Table 2: Various Estimates of the Return to the Party Membership (Dependent variable: log earnings)

\begin{tabular}{|c|c|c|c|c|c|c|}
\hline & \multirow{2}{*}{$\begin{array}{c}\text { Whole } \\
\text { sample } \\
\text { OLS } \\
(1)\end{array}$} & \multicolumn{5}{|c|}{ Twins } \\
\hline & & $\begin{array}{l}\text { OLS } \\
(2)\end{array}$ & $\begin{array}{l}\mathrm{FE} \\
(3)\end{array}$ & $\begin{array}{l}\text { GLS } \\
\text { (4) }\end{array}$ & $\begin{array}{l}\text { OLS } \\
(5)\end{array}$ & $\begin{array}{l}\mathrm{FE} \\
(6)\end{array}$ \\
\hline $\begin{array}{l}\text { Party } \\
\text { membership }\end{array}$ & $\begin{array}{c}0.124^{* * *} \\
(0.023)\end{array}$ & $\begin{array}{c}0.100 * * * \\
(0.037)\end{array}$ & $\begin{array}{c}0.011 \\
(0.043)\end{array}$ & $\begin{array}{c}0.013 \\
(0.042)\end{array}$ & $\begin{array}{l}-0.298 * \\
(0.158)\end{array}$ & $\begin{array}{l}-0.003 \\
(0.169)\end{array}$ \\
\hline $\begin{array}{l}\text { Sum of party } \\
\text { membership }\end{array}$ & & & & $\begin{array}{c}0.067 * * \\
(0.032)\end{array}$ & & \\
\hline Age & $\begin{array}{c}0.027 * * * \\
(0.008)\end{array}$ & $\begin{array}{c}0.050 * * * \\
(0.014)\end{array}$ & & $\begin{array}{c}0.048 * * * \\
(0.012)\end{array}$ & $\begin{array}{c}0.056^{* * *} \\
(0.014)\end{array}$ & \\
\hline $\begin{array}{l}\text { Age-squared } \\
(1 / 100)\end{array}$ & $\begin{array}{c}-0.026 * * \\
(0.010)\end{array}$ & $\begin{array}{c}-0.057 * * * \\
(0.020)\end{array}$ & & $\begin{array}{c}-0.055^{* * *} \\
(0.018)\end{array}$ & $\begin{array}{c}-0.069 * * * \\
(0.021)\end{array}$ & \\
\hline $\begin{array}{l}\text { Age*party } \\
\text { membership }\end{array}$ & & & & & $\begin{array}{l}0.011^{* *} \\
(0.004)\end{array}$ & $\begin{array}{c}0.001 \\
(0.005)\end{array}$ \\
\hline Male & $\begin{array}{c}0.189 * * * \\
(0.020)\end{array}$ & $\begin{array}{c}0.179 * * * \\
(0.033)\end{array}$ & & $\begin{array}{c}0.180 * * * \\
(0.032)\end{array}$ & $\begin{array}{c}0.180 * * * \\
(0.033)\end{array}$ & \\
\hline Education & $\begin{array}{c}0.063 * * * \\
(0.003)\end{array}$ & $\begin{array}{c}0.070 * * * \\
(0.005)\end{array}$ & $\begin{array}{c}0.032 * * * \\
(0.010)\end{array}$ & $\begin{array}{c}0.033^{* * *} \\
(0.009)\end{array}$ & $\begin{array}{c}0.070 * * * \\
(0.005)\end{array}$ & $\begin{array}{c}0.032^{* * *} \\
(0.010)\end{array}$ \\
\hline $\begin{array}{l}\text { Sum of } \\
\text { education }\end{array}$ & & & & $\begin{array}{c}0.022 * * * \\
(0.005)\end{array}$ & & \\
\hline Twin pairs & & 725 & 725 & 725 & 725 & 725 \\
\hline Observations & 3135 & 1450 & 1450 & 1450 & 1450 & 1450 \\
\hline R-squared & 0.17 & 0.21 & 0.02 & 0.22 & 0.22 & 0.02 \\
\hline
\end{tabular}

Note: Robust standard errors in parentheses. OLS and GLS regressions allow clustering at the family level. * significant at $10 \%$; ** significant at $5 \%$; *** significant at $1 \%$. The OLS and GLS regressions include city dummies. 
Table 3: Between-Families and Within-Twin-Pair Correlations of the Party Membership and Other Variables (435 twin pairs)

\begin{tabular}{|c|c|c|c|c|}
\hline & \multicolumn{2}{|c|}{ Between-family } & \multicolumn{2}{|c|}{ Within-family } \\
\hline & \multicolumn{2}{|c|}{ Correlation with } & \multicolumn{2}{|c|}{ Correlation with } \\
\hline & Variance & Party membership & Variance & Party membership \\
\hline Party membership & 0.1622 & -- & 0.1699 & -- \\
\hline \multirow[t]{2}{*}{ Log earnings } & 0.2835 & $0.2750 * * *$ & 0.1338 & 0.0315 \\
\hline & & $(<0.01)$ & & $(0.3965)$ \\
\hline \multirow[t]{2}{*}{ Education } & -- & $0.2285^{* * *}$ & -- & $0.1587^{* * *}$ \\
\hline & & $(<0.01)$ & & $(<0.01)$ \\
\hline \multirow[t]{2}{*}{ Tenure } & -- & $0.2990 * * *$ & -- & 0.0123 \\
\hline & & $(<0.01)$ & & $(0.74)$ \\
\hline \multirow[t]{2}{*}{ Marital status } & -- & $0.1990 * * *$ & -- & -0.0327 \\
\hline & & $(<0.01)$ & & $(0.38)$ \\
\hline \multirow[t]{2}{*}{ Spouse's education } & -- & $0.1555^{* * *}$ & -- & 0.0513 \\
\hline & & $(<0.01)$ & & $(0.32)$ \\
\hline
\end{tabular}

Note: Significant level in parentheses. * significant at 10\%; ** significant at 5\%; *** significant at $1 \%$.

Between-family correlation are correlations of average family Party membership (average of the twins) with average family characteristics, and within-twin-pair correlations are correlations of the within-twin-pair differences in education with within-twin-pair differences in other characteristics 
Table 4: The External Effect and Other Benefits of the Party Membership

\begin{tabular}{|c|c|c|c|c|c|c|}
\hline \multirow{2}{*}{$\begin{array}{l}\text { Dependent variable } \\
\text { Sample }\end{array}$} & \multicolumn{5}{|c|}{ Log earnings } & \multirow{2}{*}{$\begin{array}{c}\text { Government } \\
\text { official dummy } \\
\text { Twins }\end{array}$} \\
\hline & Twins & Twins & Twins & Non-twin & Non-twin & \\
\hline \multirow[t]{2}{*}{ Regression model } & GLS & OLS & OLS & OLS & OLS & $\mathrm{FE}$ \\
\hline & (1) & (2) & (3) & (4) & (5) & (6) \\
\hline \multirow[t]{2}{*}{ Party membership } & 0.148 & $0.100 * * *$ & & $0.108 * * *$ & & $0.123^{* * *}$ \\
\hline & $(0.096)$ & $(0.037)$ & & $(0.041)$ & & $(0.028)$ \\
\hline \multirow[t]{2}{*}{ Sibling’s Party membership } & & & $0.111^{* * *}$ & & 0.022 & \\
\hline & & & $(0.039)$ & & $(0.053)$ & \\
\hline \multirow[t]{2}{*}{ Only sibling is Party member } & 0.115 & & & & & \\
\hline & $(0.081)$ & & & & & \\
\hline \multirow{2}{*}{$\begin{array}{l}\text { Sum of own and sibling's Party } \\
\text { membership }\end{array}$} & -0.006 & & & & & \\
\hline & $(-0.11)$ & & & & & \\
\hline \multirow[t]{2}{*}{ Age } & $0.047 * * *$ & $0.050 * * *$ & $0.050 * * *$ & 0.003 & 0.015 & \\
\hline & $(0.012)$ & $(0.014)$ & $(0.014)$ & $(0.023)$ & $(0.025)$ & \\
\hline \multirow[t]{2}{*}{ Age-squared (1/100) } & -0.053 & $-0.057 * * *$ & $-0.057 * * *$ & 0.003 & -0.000 & \\
\hline & $(0.018)$ & $(0.020)$ & $(0.020)$ & $(0.026)$ & $(0.000)$ & \\
\hline \multirow[t]{2}{*}{ Male } & $0.178 * * *$ & $0.179 * * *$ & $0.178 * * *$ & $0.250 * * *$ & $0.155^{* * *}$ & \\
\hline & $(0.032)$ & $(0.033)$ & $(0.033)$ & $(0.036)$ & $(0.053)$ & \\
\hline \multirow[t]{2}{*}{ Education } & $0.033^{* * *}$ & $0.070^{* * *}$ & $0.071^{* * *}$ & $0.062 * * *$ & $0.095 * * *$ & $0.013^{* *}$ \\
\hline & $(0.009)$ & $(0.005)$ & $(0.005)$ & $(0.008)$ & $(0.009)$ & $(0.006)$ \\
\hline \multirow{2}{*}{$\begin{array}{l}\text { Sum of own and sibling's } \\
\text { education }\end{array}$} & $0.022 * * *$ & & & & & \\
\hline & $(0.005)$ & & & & & \\
\hline Observations & 1450 & 1450 & 1450 & 922 & 922 & 1450 \\
\hline R-squared & 0.22 & 0.21 & 0.21 & 0.18 & 0.14 & 0.05 \\
\hline
\end{tabular}

Note: Robust standard errors in parentheses. Regressions of the twins sample allow clustering at the family level. * significant at 10\%; ** significant at 5\%; *** significant at $1 \%$. All OLS and GLS regressions include city dummies. 